\title{
Teachers' experienced classroom demands and autonomic stress reactions: results of a pilot study and implications for process-oriented research in vocational education and training
}

\author{
Tobias Kärner ${ }^{1 *}$ (D) and Jana Höning ${ }^{2}$
}

*Correspondence: tobias. kaerner@uni-hohenheim.de ${ }^{1}$ University of Hohenheim, Stuttgart, Germany

Full list of author information is available at the end of the article

\begin{abstract}
Background: To examine relationships between teachers' experienced classroom demands and autonomic stress reactions, we report the results of a pilot study. Based on an integrative literature review, we identified and described the following situational classroom demands: time and work pressure (including missing rest periods, time pressure, and pressure to get through the subject matter), vocal strain, uncertainty concerning the subject matter, uncertainty concerning didactical decisions, achievement-related diversity in class, lack of social appreciation, disquietude in class, classroom disturbances, behavioral problems of students, insufficient skills and concentration of students, and insufficient motivation of students.

Method: These identified categories of teachers' situational classroom demands are the basis for the empirical item identification and selection (Study A). The identified items were used in a single-case, short-term longitudinal study in which we examined relationships between experienced classroom demands and autonomic stress reactions as well as between autonomic stress reactions and affective stress experience via first-order vector autoregressive modeling (Study B).
\end{abstract}

Results: Concerning our hypotheses, we found evidence that some of the experienced classroom demands ("I cannot respond to students' different needs"; "There is disquietude in class") had time-lagged associations with autonomic stress measures. Furthermore, we found that physiological arousal triggers affective stress experience due to a time-lagged effect.

Conclusion: The research approach and results of our pilot study can be the basis for further process-oriented research in vocational education and training (VET). From a practical point of view, our results on experienced classroom demands could be used in VET teacher education to prepare student teachers for specific skills to cope with such demands.

Keywords: Teacher stress, Classroom demands, Heart rate, Heart-rate variability, Experience sampling, Ambulatory physiological assessment 


\section{Introduction}

Teachers are exceptionally vulnerable to feeling stressed at work and to suffering from stress-related chronic diseases (e.g. Kaerner et al. 2016; Kyriacou 2011; Rothland and Terhart 2007; Schaarschmidt and Kieschke 2007; Sembill 2015). According to Kyriacou and Sutcliffe (1978, p. 2):

"Teacher stress may be defined as a response of negative affect (such as anger or depression) by a teacher usually accompanied by potentially pathogenic physiological and biochemical changes (such as increased heart rate or release of adrenocorticotrophic hormones into the bloodstream) resulting from aspects of the teacher's job and mediated by the perception that the demands made upon the teacher constitute a threat to his self-esteem or well-being and by coping mechanisms activated to reduce the perceived threat."

The model of Kyriacou and colleagues is based on the basic ideas of the transactional stress model of Lazarus and colleagues (e.g., Lazarus and Folkman 1984). Thus, the model is generic concerning its basic psychological ideas. Even though the model of Kyriacou was first published in 1978, it has been continuously used in psychological teacher stress research and has been applied in further applications (e.g., Kyriacou 2001, 2011; Kyriacou and Sutcliffe 1978). Figure 1 illustrates Kyriacou and Sutcliffe's (1978 et passim) model of teacher stress. Because of the complexity of the model, in our pilot study we only focus on the sources of stress in classroom work (Fig. 1, box 1; see Sect. "Literature review on teachers' situational classroom demands" for a detailed description) and on teachers' stress outcomes in terms of physiological response correlates and negative affect (Fig. 1, box 5; see Sect. "Physiological and affective response correlates of stress" for a detailed description).

Existing literature among teacher demands (e.g., Kramis-Aebischer 1995; Kyriacou 2001; Rudow 1994; Schumann 2019; Van Dick 1999) shows that stressors are categorized referring to different levels of analysis. Van Dick (1999), for example, differentiates between stressors at the personal level (e.g., conflicts with colleagues), the school level (e.g., class size), and the system level (e.g., legal requirements). Considering that teachers are exposed to class-related stressors every day, existing approaches (e.g., Christ et al. 2004; Rudow 2000; Van Dick 1999) lack the theoretical foundation and

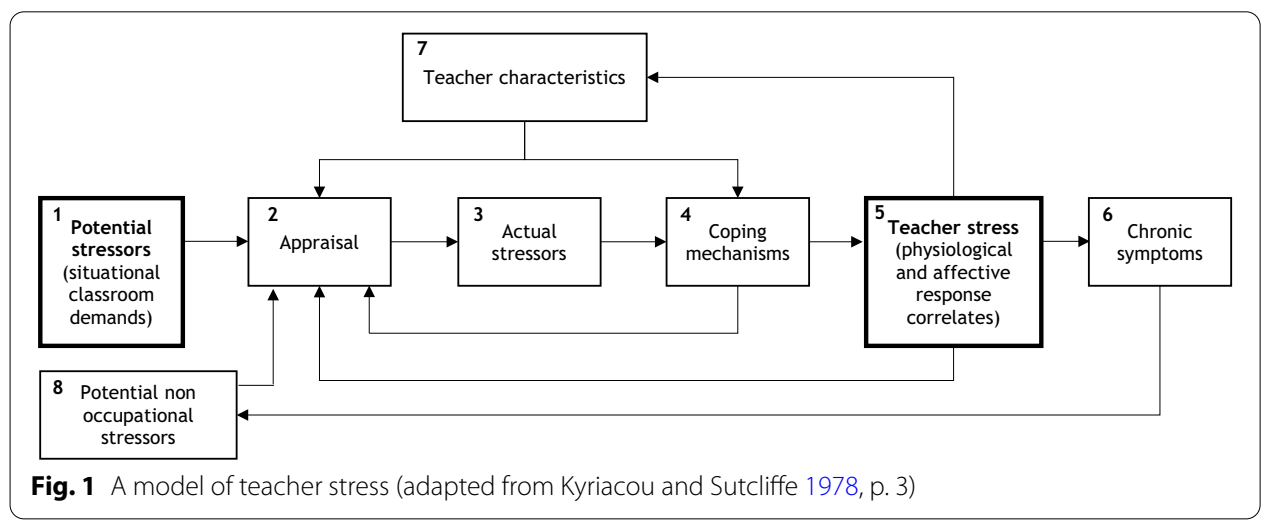


empirical investigation of teachers' experienced situational classroom demands that occur during education. Thus, we pursue the following research aims:

- Categorize teachers' classroom demands based on a literature review (Sect. "Literature review on teachers' situational classroom demands") as a basis for the formulation of the items that are used in the empirical Studies A and B;

- Identify teachers' classroom demands empirically via a questionnaire study (Sect. “Study A: Empirical identification of teachers' classroom demands and item selection"), resulting in items that are used in the single-case, short-term longitudinal study; and

- Examine the relationships between classroom demands and autonomic stress reactions as well as between autonomic stress reactions and affective stress experience via a single-case, short-term longitudinal study (Sect. "Study B: Examining relationships between teachers' classroom demands and autonomic stress reactions as well as between autonomic stress reactions and affective stress experience").

\section{Literature review on teachers' situational classroom demands}

To categorize teachers' classroom-related situational stressors, we reviewed existing classifications among teacher demands as well as the educational literature. A literature search was conducted via systematic keyword search using international and German databases (VOCEDplus, PSYNDEX, PsycINFO, PsycArticles, ERIC, Teacher Reference Center, and Fachportal Paedagogik; examples of keywords: teacher", class", demand*, stress $^{*}$, situation $\left.{ }^{*}\right)$. The classroom-related situational stressors found in the literature were summarized by the authors, bearing in mind that some of the categories partly overlap. Table 1 summarizes the identified demand categories that are described below.

1) Time and work pressure (including the following subcategories 1a, 1b, and 1c)

1a) Missing rest periods: During class, teachers have to monitor constantly what is going on in the classroom. That is what Kounin (1970) describes as "with-itness" in terms of a permanent perceptual "omnipresence." Due to a high degree of classroom interaction density and many decisions that have to be made (Hillert et al. 2013; Miller 1989), and due to what Weinert and Schrader (1986) call a permanent "pressure to act," teachers are constantly mentally activated and strained (Krause 2004; Rothland 2009; Rudow 2000). Thus, during class, teachers do not have sufficient rest periods to withdraw and calm down (Krause 2004; Krause and Dorsemagen 2007; Kaempf and Krause 2004; Rudow 1994).

1b) Time pressure: Kyriacou (2001) identified "time pressures and workload" as one of the main sources of class-related stress. During class, teachers have to pursue different (possibly conflicting) goals that have to be chronologically prioritized and realized (Krause 2003; Krause and Dorsemagen 2007). For example, time restrictions (e.g., lesson periods of $45 \mathrm{~min}$ ) might impede teachers from looking after students' individual learning problems (Kyriacou and Sutcliffe 1978; Sol- 


\section{Table 1 Literature review on teachers' situational classroom demands}

\begin{tabular}{l} 
No Demand category \\
\hline 1 Time and work pressure (including the following \\
subcategories $1 \mathrm{a}, 1 \mathrm{~b}$, and $1 \mathrm{c}$ ) \\
1a $\begin{array}{c}\text { Missing rest periods due to permanent mental } \\
\text { activation and a permanent "pressure to act" }\end{array}$ \\
1b Time pressure due to time restrictions (e.g. lesson \\
periods of 45 min) and chronologically conflicted \\
goals \\
1c Pressure to get through the scheduled subject \\
matter \\
Vocal strain due to permanent speaking \\
3 Uncertainty concerning subject matter due to \\
subjective or objective knowledge deficits \\
Uncertainty concerning didactical decisions and \\
unpredictability of the course of the lesson
\end{tabular}

5 Achievement-related diversity in class and the perceived responsibility to fulfil the teacher's role to respond to students' different needs

6 Lack of social appreciation due to problematic teacher-student relationships

7 Disquietude in class due to disturbing noise

8 Classroom disturbances through disruptive students

9 Behavioural problems of students (e.g. aggressive behaviour and conflicts between students)

10 Problems to address the scheduled subject matter due to insufficient skills and concentration of students

11 Insufficient motivation, involvement, and participation of students
Reference literature

(Hillert et al. 2013; Kaempf and Krause 2004; Kounin

1970; Krause 2004; Krause and Dorsemagen 2007 . Miller 1989; Rothland 2009; Rudow 1994, 2000; Weinert and Schrader 1986)

(Dunham and Varma 1998; Friesen and Williams 1985; Kaempf and Krause 2004; Kaerner 2015; Krause and Dorsemagen 2007; Krause 2003, 2004; Kyriacou and Sutcliffe 1978; Kyriacou 2001; Seifried 2009; Solman and Feld 1989; Spanhel and Hueber 1995)

(Dubs 1989; Herzog 2007; Kaerner 2015; Seifried 2009)

(Rudow 1994; Schoenwaelder et al. 2003; Seiboth 2015)

(Kaerner 2015; Kramis-Aebischer 1995; Rudow 1994; Wulk 1988)

(Baumert and Kunter 2006; Gebert 1981; Grimm 1993; Helsper 2003; Kaerner et al. 2020; Kramis-Aebischer 1995; Paseka et al. 2018; Rudow 1994; Soltau and Mienert 2010; Wulk 1988)

(Brown and Ralph 1998; Dunham and Bath 1998; Grimm 1993; Herzog 2007; Kaerner et al. 2021; Kyriacou and Sutcliffe 1978; Kyriacou 2001; Needle et al. 1981; Meder et al. 2008; Pieren and Schaerer 1994; Rothland and Terhart 2007; Rudow 1994; Seiboth 2015; Spanhel and Hueber 1995; Stiller 2015; Trachsler et al. 2006; Van Dick 1999; Wulk 1988)

(Donker et al. 2018; Grimm 1993; Kaerner 2015; Seiboth 2015; Seifried 2009; Seifried and Sembill 2005; Sembill 1987, 2004; Wulk 1988)

(Bieri 2002; Kaempf and Krause 2004; Kaerner 2015; Kramis-Aebischer 1995; Krause 2004; Kyriacou and Sutcliffe 1978; Meder et al. 2008; Ritterstaedt et al. 1980; Rudow 1994; Schoenwaelder et al. 2003; Seiboth 2015; Wulk 1988)

(Belt and Belt 2017; Blase 1986; Dunham 1981; Grimm 1993; Haebler and Kunz 1985; Kaempf and Krause 2004; Krause and Dorsemagen 2007; Krause 2004; Kyriacou 1998; Schoenwaelder et al. 2003; Seiboth 2015; Van Dick 1999; Wulk 1988)

(Bieri 2002; Herzog 2007; Kramis-Aebischer 1995; Pieren and Schaerer 1994; Schoenwaelder et al. 2003; Seiboth 2015; Spanhel and Hueber 1995; Trachsler et al. 2006; Wulk 1988)

(Bieri 2002; Blase 1986; Dunham 1981; Grimm 1993; Haebler and Kunz 1985; Kaempf and Krause 2004; Krause and Dorsemagen 2007; Krause 2003; Kyriacou and Sutcliffe 1978; Pieren and Schaerer 1994; Spanhel and Hueber 1995; Van Dick 1999; Wulk 1988)

(Bieri 2002; Blase 1986; Brown and Ralph 1998; Grimm 1993; Haebler and Kunz 1985; Kramis-Aebischer 1995; Krause and Dorsemagen 2007; Krause 2003; Kyriacou 1998, 2001; Kyriacou and Sutcliffe 1978; Needle et al. 1981; Schoenwaelder et al. 2003; Seiboth 2015; Van Dick 1999; Warwas et al. 2016; Wulk 1988) 
man and Feld 1989) because teachers have to get through the scheduled subject matter.

1c) Pressure to get through the subject matter: Closely linked to teachers' experienced time pressure, teachers experience a high workload because they have to get through the scheduled subject matter (Spanhel and Hueber 1995). Increasing amounts of curriculum-related content force teachers to teach an increasing wealth of material within unchanged lesson periods (Dubs 1989; Herzog 2007). Further, the teachers' aim to support students' individualized learning chronologically conflicts with the aim to fulfill the curriculum.

2) Vocal strain: Teachers' classroom work is characterized by high degrees of verbal communication (Wuttke 2005). Thus, teachers have to use their voice continuously, and they are physically strained due to constant speaking (Rudow 1994; Schoenwaelder et al. 2003; Seiboth 2015).

3) Uncertainty concerning subject matter: A main task of teachers is to support the learners' knowledge acquisition. Thus, teachers have to have sufficient expert knowledge in the domain they teach (Achtenhagen and Weber 2015). If teachers do not have sufficient knowledge ("objective knowledge deficits"), or if they are not confident about their domain-specific knowledge ("subjective knowledge deficits"), teachers will experience high degrees of uncertainty concerning the subject matter that has to be imparted (Kramis-Aebischer 1995; Rudow 1994; Wulk 1988).

4) Uncertainty concerning didactical decisions: During class, teachers normally do not have access to valid and reliable behavioral indicators of student characteristics and/ or to their learning experiences and progress. Thus, teachers have to make didactical decisions under uncertainty and act under uncertain conditions (Helsper 2003; Soltau and Mienert 2010). Due to information deficits, an uncertain information basis, and a lack of adequate action rules and heuristics (Kaerner et al. 2020), the course of the lesson might be experienced as uncertain and unpredictable (Baumert and Kunter 2006; Gebert 1981; Grimm 1993; Rudow 1994).

5) Achievement-related diversity in class: Addressing student diversity in the classroom with respect to both cognitive and non-cognitive prerequisites of successful learning by adapting instruction to learners' needs challenges teachers in their daily work (Corno and Snow 1986; Heinrichs and Reinke 2019; Kaerner et al. 2021; Terhart 2014). The existing literature shows that teachers experience the "ability mix" in the classroom and substantial performance differences between low and high achieving students as a main classroom stressor (Brown and Ralph 1998; Krause 2003, 2004; Krause and Dorsemagen 2007; Pieren and Schaerer 1994; Seiboth 2015; Trachsler et al. 2006; Van Dick 1999; Wulk 1988). One reason for this is that teachers have to adapt their teaching to different learners' needs (Bruehwiler and Blatchford 2011). Another reason is that teachers perceive the responsibility to fulfill their role to respond to students' different needs. Teachers are stressed because they have to meet students' and parents' expectations to fulfill their roles of being a "learning coach" on the one hand and a "student evaluator" on the other hand (Grimm 1993; Rudow 1994; Trachsler et al. 2006). Thus, teachers might experience role conflicts and ambiguity when trying to find the right mixture between challenging and developing stu- 
dents with different strengths and weaknesses (Dunham and Bath 1998; Kyriacou 2001; Rothland and Terhart 2007).

6) Lack of social appreciation: Problematic teacher-student relationships, a crude communication atmosphere in the classroom, or conflicts between the teacher and students can lead to a lack of social appreciation and a feeling of not being taken seriously (Grimm 1993; Seiboth 2015; Sembill 1987, 2004; Wulk 1988).

7) Disquietude in class: Disquietude due to disturbing noise stresses teachers because they might feel they have to raise their voices against the noise level in the classroom. They also have to perform classroom management to get students to quiet down (Bieri 2002; Kramis-Aebischer 1995; Krause 2004; Kyriacou and Sutcliffe 1978; Rudow 1994; Schoenwaelder et al. 2003; Seiboth 2015; Van Dick 1999).

8) Classroom disturbances: Classroom disturbances can be a result of discipline problems of some students (Blase 1986; Dunham 1981; Haebler and Kunz 1985; Needle et al. 1981; Van Dick 1999) or what Kyriacou (1998) calls "overt indiscipline." If the planned course of the lesson is, for instance, disrupted by students, teachers are stressed because their schedule is interrupted, resulting (among other things) in time pressure and pressure to get through the subject matter (Grimm 1993; Krause and Dorsemagen 2007; Seiboth 2015; Wulk 1988).

9) Behavioral problems of students: Another classroom-related stressor that is closely related to classroom disturbances and discipline problems of students is students' unsocial and aggressive behavior (Bieri 2002; Kramis-Aebischer 1995; Pieren and Schaerer 1994; Seiboth 2015; Trachsler et al. 2006). Thus, students can have behavioral problems that result in conflict between students and aggression against teachers (Spanhel and Hueber 1995; Wulk 1998).

10) Insufficient skills and concentration of students: Lacking competencies, insufficient skills, and lacking concentration are reasons that some students are not able to follow the subject matter. Thus, teachers are faced with the problem to address the scheduled subject matter and students who struggle to follow the class (Grimm 1993; Haebler and Kunz 1985; Kaempf and Krause 2004; Van Dick 1999; Wulk 1988).

11) Insufficient motivation of students: Aside from lacking skills and concentration, some students might be unmotivated, not involved, and not participate in class (Haebler and Kunz 1985; Kramis-Aebischer 1995; Schoenwaelder et al. 2003; Van Dick 1999; Warwas et al. 2016; Wulk 1988). Thus, teaching students who lack motivation is a main challenge teachers face during education (Kyriacou 2001). The fact that some students are passive and do not take an active part in class might result, for instance, from diverging goals between teachers (e.g., addressing the subject matter) and students (e.g., talking to a friend about plans for the weekend) (Krause 2003; Krause and Dorsemagen 2007).

\section{Physiological and affective response correlates of stress}

After categorizing different situational classroom demands as potential stressors for teachers, we now describe the response correlates of stress in greater detail (see Fig. 1, box 5). In a general way and from a somatic point of view, Selye (1973, p. 692) defines stress as "the nonspecific response of the body to any demand made upon it." Aside 
from neuroendocrine systems, the autonomic nervous system (ANS) is involved in the physiological stress reaction (Kemeny 2003). The situational adaptability of the ANS is indicated by the antagonistic relationship between the sympathetic nervous system (SNS) and the parasympathetic nervous system (PNS). The SNS enables the organism to adapt rapidly to demanding situations, and the PNS controls physiological resting functions. The dynamic interplay between the SNS and PNS, and thus the adaptability of the ANS according to changing situational demands, can be operationalized by changes in heart rate (HR) and heart rate variability (HRV), both of which are indicators of the cardiac system's activity (Kemeny 2003; Task Force of the European Society of Cardiology and The North American Society of Pacing and Electrophysiology 1996). HR (measured in beats per minute $[\mathrm{bpm}]$ ) indicates the contractions of the heart per minute. As a time-domain measure of HRV, the root mean square of successive differences (RMSSD, measured in milliseconds [ms]) is operationalized as the square root of the mean of the sum of the squares of differences between adjacent NN (normal-tonormal) intervals. As a frequency domain measure of HRV, the LF/HF ratio indicates the power in the low frequency range (LF, $0.04-0.15 \mathrm{~Hz}$, measured in $\left.\mathrm{ms}^{2}\right)$ in relation to the power in the high frequency range (HF, $0.15-0.4 \mathrm{~Hz}$, measured in $\left.\mathrm{ms}^{2}\right)$. LF primarily reflects the activity of the SNS, and HF primarily reflects the activity of the PNS (Task Force of the European Society of Cardiology and The North American Society of Pacing and Electrophysiology 1996). Existing literature (Castaldo et al. 2015; JaervelinPasanen et al. 2018; Kim et al. 2018) predominantly indicates increases of the HR and the LF/HF ratio and decreases of the RMSSD under stress (Table 2).

Table 2 Changes of HR, RMSSD, and the LF/HF ratio under stress

\begin{tabular}{|c|c|c|c|}
\hline ANS indicators & Change & Measures and correlates & Reference literature \\
\hline \multirow[t]{3}{*}{$\mathrm{HR}$} & \multirow[t]{3}{*}{$\uparrow \downarrow$} & Job Stress Questionnaire & Clays et al. (2011) \\
\hline & & Simulated emergency case & Kaegi et al. (1999) \\
\hline & & Speech task & Schubert et al. (2009) \\
\hline \multirow[t]{7}{*}{ RMSSD } & \multirow[t]{6}{*}{$\downarrow \downarrow$} & Effort-Reward Imbalance Questionnaire & Garza et al. (2015) \\
\hline & & Game task & Li et al. (2009) \\
\hline & & Occupational Stress Questionnaire & Lindholm et al. (2009) \\
\hline & & Job Content Questionnaire & Loerbroks et al. (2010) \\
\hline & & Physical-mental task & Taelman et al. (2011) \\
\hline & & Effort-Reward Imbalance Questionnaire & Uusitalo et al. (2011) \\
\hline & $\downarrow$ & Academic examination & Tharion et al. (2009) \\
\hline \multirow[t]{9}{*}{ LF/HF ratio } & \multirow[t]{3}{*}{$\uparrow \uparrow$} & Job Stress Questionnaire & Clays et al. (2011) \\
\hline & & Effort-Reward Imbalance Questionnaire & Garza et al. (2015) \\
\hline & & Arithmetic aloud task & Traina et al. (2011) \\
\hline & \multirow[t]{4}{*}{$\uparrow$} & Computer work task & Hjortskov et al. (2004) \\
\hline & & Stroop Colour Word Test & Kofman et al. (2006) \\
\hline & & Academic examination & Papousek et al. (2010) \\
\hline & & Speech task & Schubert et al. (2009) \\
\hline & $\downarrow \downarrow$ & Job Content Questionnaire & Hernández-Gaytan et al. (2013) \\
\hline & $\downarrow$ & Academic examination & Tharion et al. (2009) \\
\hline
\end{tabular}

$\downarrow \downarrow(\uparrow \uparrow)$ significant lower (higher) under stress $(p<0.05): \downarrow(\uparrow)$ - lower (higher) under stress $(p>0.05)$; abbreviations: HR (heart rate), LF (low frequency domain) / HF (high frequency domain) ratio, RMSSD (square root of the mean of the sum of the squares of differences between adjacent NN (normal-to-normal) intervals); overview adapted from Castaldo et al. (2015), Jaervelin-Pasanen et al. (2018), and Kim et al. (2018) 
In addition to the somatic stress reactions, there are also affective reactions. According to $\operatorname{Cox}(1978$, p. 26), "it is the experience of stress which represents a central and personal element $[\ldots]$ For the individual it is one of the most obvious aspects of the occurrence of stress; it is what they feel." There is an ongoing philosophical and psychological discussion on the relationship between somatic and psychological phenomena (see Beck 1994 for a discussion). In accordance with Schachter and Singer (1962), Rausch (2011), and Sembill and Kaerner (2018), (2020), we hold that autonomic somatic processes primarily trigger psychological experiences. However, it is assumed that, in the course of time, somatic processes interact with psychological experiences.

\section{Research aims and hypotheses}

Based on the reviewed literature, we aim to investigate associations between teachers' experienced situational classroom demands and physiological and affective response correlates of stress. As written in Sect. "Introduction" and in reference to the model of teacher stress by Kyriacou and Sutcliffe (1978; Fig. 1), we limit our analysis to relationships between potential classroom stressors and teachers' stress reactions.

Thus, we must first identify the categorized classroom demands (Table 1) empirically and select corresponding items (Study A). Second, we must examine relationships (a) between classroom demands and autonomic stress reactions as well as (b) between autonomic stress reactions and affective stress experience (Study B). Here, we hypothesize the following relationships:

a) Teachers' classroom demands should be positively associated with the HR and the LF/HF ratio, and they should be negatively associated with the RMSSD. Because of possible time-lagged effects of a stressor on the physiological response correlates of stress, we must examine simultaneously not only effects at time t but also timelagged effects of $t-1$ on $t$.

b) Further, we hypothesize that autonomic stress reactions trigger affective stress experience. Thus, we must examine time-lagged effects of autonomic stress reactions on affective experience.

\section{Study A: empirical identification of teachers' classroom demands and item selection \\ Method and sample}

To operationalize the identified demand categories (see Sect. "Literature review on teachers' situational classroom demands", Table 1) via items to use them in the single-case, short-term longitudinal study (Study B), we first conducted a questionnaire study using convenience sampling. The questionnaire was provided via an online tool. In total, 108 practicing teachers ( 83 females, 24 males, 1 unknown) with a mean age of 38.2 years (standard deviation $[S D]=9.5$, range from 18 to 64 years) and mean teaching experience of 11 years ( $S D=9.1$, range from 0 to 41 years) completed the questionnaire. Participants worked at the following school types: primary schools (31.5\%), secondary schools (25.9\%), common schools (19.4\%), vocational schools (15.7\%), and special needs schools (7.4\%). 


\section{Item development and selection}

First, based on the identified classroom demands, 38 items were formulated by the authors and discussed with a practicing teacher concerning contentual understandability and meaningfulness. The items were presented via questionnaire, and the participants were asked to put themselves in a position to give a lesson and imagine how demanding they would evaluate the presented situations. The items were rated on a 5-point Likert scale: 1 ="not demanding," 2 ="less demanding," 3 ="neutral," $4=$ "demanding," and $5=$ "very demanding." Second, based on the data, we conducted a principal component analysis, and the 38 items condensed to 11 factors that explained $70.7 \%$ of the total variance. As empirical item selection criteria, factor loadings must be greater than 0.4 (range between 0.405 and 0.869 ), and items must have a high mean value within the corresponding factor. For content-related item selection criteria, the chosen items must represent the identified classroom demands (Sect. "Literature review on teachers' situational classroom demands"). Principal component analysis shows that classroom demands concerning missing rest periods, time pressure, and pressure to get through the subject matter condense to one scale that describes time and work pressure (Cronbach's alpha $=0.754)$. Balancing empirical item selection criteria and content-related item selection criteria, the following items were selected:

1. Time and work pressure

1a) Missing rest periods: "I am lacking rest periods."

1b) Time pressure: "I am under time pressure."

1c) Pressure to get through the subject matter: "I must get through the subject matter."

2. Vocal strain: "I cannot rest my voice."

3. Uncertainty concerning subject matter: "I do not feel certain about the subject matter."

4. Uncertainty concerning didactical decisions: "I have to make didactical decisions under uncertainty."

5. Achievement-related diversity in class: "I cannot respond to students' different needs."

6. Lack of social appreciation: "I do not feel taken seriously."

7. Disquietude in class: "There is disquietude in class."

8. Classroom disturbances: "Some students are disturbing my class."

9. Behavioral problems of students: "Some students show behavioral problems."

10. Insufficient skills and concentration of students: "Some students are not able to follow the subject matter."

11. Insufficient motivation of students: "Some students are unmotivated."

\section{Study A results}

Table 3 contains descriptive data and Spearman correlations. Participants evaluated the uncertainty concerning didactical decisions as least demanding (mean $[M]=2.83$ ), and they evaluated behavioral problems of students as most demanding $(M=4.16)$. The standard deviations ranged from 0.76 to 1.36 points, whereby the lowest standard 


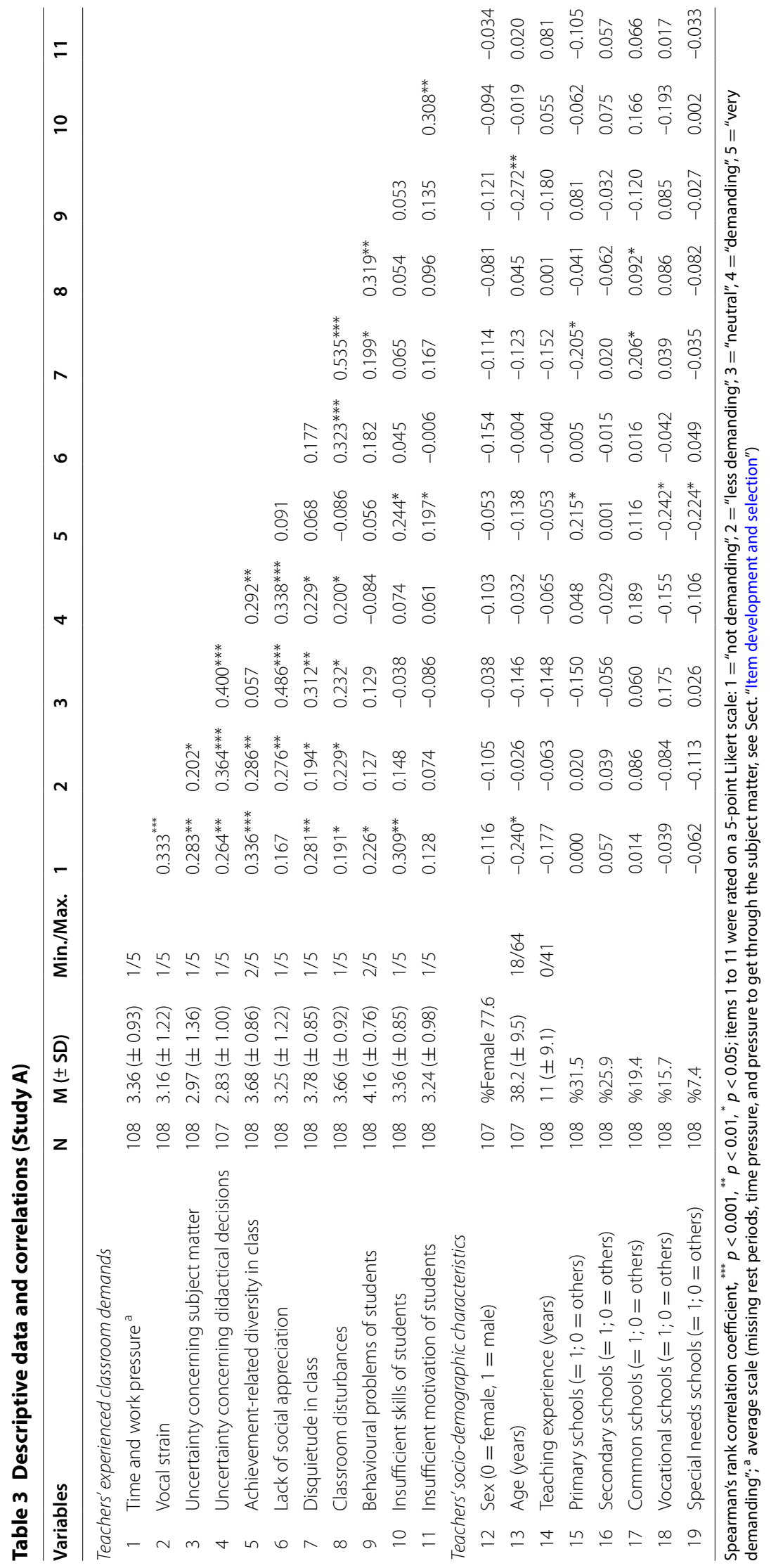


deviation is in the evaluation of behavioral problems of students, and the highest standard deviation is in the evaluation of the uncertainty concerning didactical decisions.

The Spearman's rank correlation coefficients show significant positive correlations between experienced classroom demands, whereby the highest significant positive correlation appears between disquietude in class and classroom disturbances $\left(r_{s}=0.535\right)$, and the lowest significant positive correlation between time and work pressure and classroom disturbances $\left(r_{s}=0.191\right)$. The negative correlations between experienced classroom demands are not significant.

Teachers' experienced classroom demands are not significantly correlated with sex, teaching experience, or working at a secondary school. The older the participants, the less demanding they evaluate time and work pressure $\left(r_{\mathrm{s}}=-0.240\right)$ and behavioral problems of students $\left(r_{\mathrm{s}}=-0.272\right)$; this phenomenon may be a result of work experience. Participants who work at primary schools evaluate the demand of achievementrelated diversity in class and the perceived responsibility to fulfill the teachers' role to respond to students' different needs as more demanding compared with participants who work at other schools $\left(r_{\mathrm{s}}=0.215\right)$. Participants who work at vocational schools $\left(r_{\mathrm{s}}=-0.242\right)$ or special needs schools $\left(r_{\mathrm{s}}=-0.224\right)$ evaluate diversity in class as less demanding compared with participants from other schools. Vocational school teachers evaluate problems to address the scheduled subject matter due to insufficient skills and concentration of students as less demanding compared with participants who work at other schools $\left(r_{\mathrm{s}}=-0.193\right)$. Primary school teachers evaluate disquietude and noise in class as less demanding compared with others $\left(r_{\mathrm{s}}=-0.205\right)$. Common school teachers evaluate disquietude and noise in class $\left(r_{\mathrm{s}}=0.206\right)$ as well as classroom disturbances $\left(r_{\mathrm{s}}=0.092\right)$ as more demanding compared with others. These correlational patterns may result, among other things, from different degrees of student diversity and educational goals in different types of schools. However, the sample is not representative and the findings are not generalizable.

In summary, in Study A we identified empirically the categorized teachers' classroom demands. Even though some of the categories partly overlap, the results show sufficient discriminatory power between the items that were used in the single-case, short-term longitudinal study described below.

\section{Study B: examining relationships between teachers' classroom demands and autonomic stress reactions as well as between autonomic stress reactions and affective stress experience Method and sample}

To examine relationships between classroom demands and autonomic stress reactions as well as between autonomic stress reactions and affective stress experience, we conducted a single-case, short-term longitudinal study. Potential participants were asked to participate in the study, and we chose a teacher who agreed to participate. Hence, the current sample is a convenience sample. The participant, a 31-year-old female teacher, has worked since 2014 at a German high school and teaches economics in grades $8,10,11$, and 12 . The participant was observed over a period of three 
weeks; we gathered 66 observation points in total with a mean time lag $(t-1 \rightarrow t)$ of about 26 min.

For the realization of our single-case study, we used a smartphone-based experience sampling application (Movisens GmbH, Karlsruhe, Germany). At randomly chosen points in time, the participant was asked how she felt at the moment. According to Verhagen et al. (2016), assessments are collected using a random time sampling protocol, and we choose a stratified random schedule with restricted intervals: every $45 \mathrm{~min}$ there were three measures with a time difference of at least $10 \mathrm{~min}$. The items (see Sect. 'Study A: Empirical identification of teachers' classroom demands and item selection") for assessing the participant's experienced classroom demands were rated on a 5 -point Likert scale from $1=$ "I strongly disagree" to $5=$ "I strongly agree." The participant's affective states were rated on a 5-point Likert scale from $1=$ "relaxed" to $5=$ "stressed" (cf. Schallberger 2005).

The participant's autonomic reactivity was measured continually during the observation period via a psycho-physiological ambulatory measurement system for the assessment of electrocardiography (ECG) signals (Movisens GmbH, Karlsruhe, Germany). For statistical analysis, the assessed ECG measures were aggregated via arithmetic means ( $2 \mathrm{~min}$ before the experience sampling signal, $2 \mathrm{~min}$ after the experience sampling signal, and the minute including the experience sampling signal) in order to synchronise them with experienced classroom demands and affective states. The following ECG indices were assessed: HR (bpm), RMSSD (ms) as a time-domain measure of HRV, and the LF/HF ratio as a frequency domain measure of HRV (see Sect. "Physiological and affective response correlates of stress").

\section{Study B results}

\section{Descriptive data and correlations}

Table 4 contains descriptive data and Spearman correlations among the 66 observations of our single case. The participant evaluated the lack of social appreciation as least demanding $(M=1.23)$, and she evaluated the uncertainty about didactical decisions as most demanding $(M=2.58)$. The standard deviations range from 0.42 to 0.75 points, whereby the lowest standard deviation is for the evaluation of the lack of social appreciation, and the highest standard deviation is for the evaluation of the uncertainty about didactical decisions. With respect to the scale range from $1=$ "I strongly disagree" to $5=$ "I strongly agree," the participant's evaluations of experienced classroom demands show only below-average values. Descriptive data of affective states show that the participant was relatively "relaxed" $(M=1.42, S D=0.53)$ within the period of observation (possible range from $1=$ "relaxed" to $5=$ "stressed"). Measures of HR, RMSSD, and the LF/HF ratio show normal values (cf. Task Force of the European Society of Cardiology and The North American Society of Pacing and Electrophysiology 1996).

The Spearman's rank correlation coefficients show significant positive correlations between experienced classroom demands, whereby the highest significant positive correlation appears between classroom disturbances and disquietude in class $\left(r_{s}=0.497\right)$, and the lowest significant positive correlation is between insufficient student skills and behavioral problems of students $\left(r_{s}=0.243\right)$. The negative correlations between experienced classroom demands are not significant. The participant's states of actual stress 


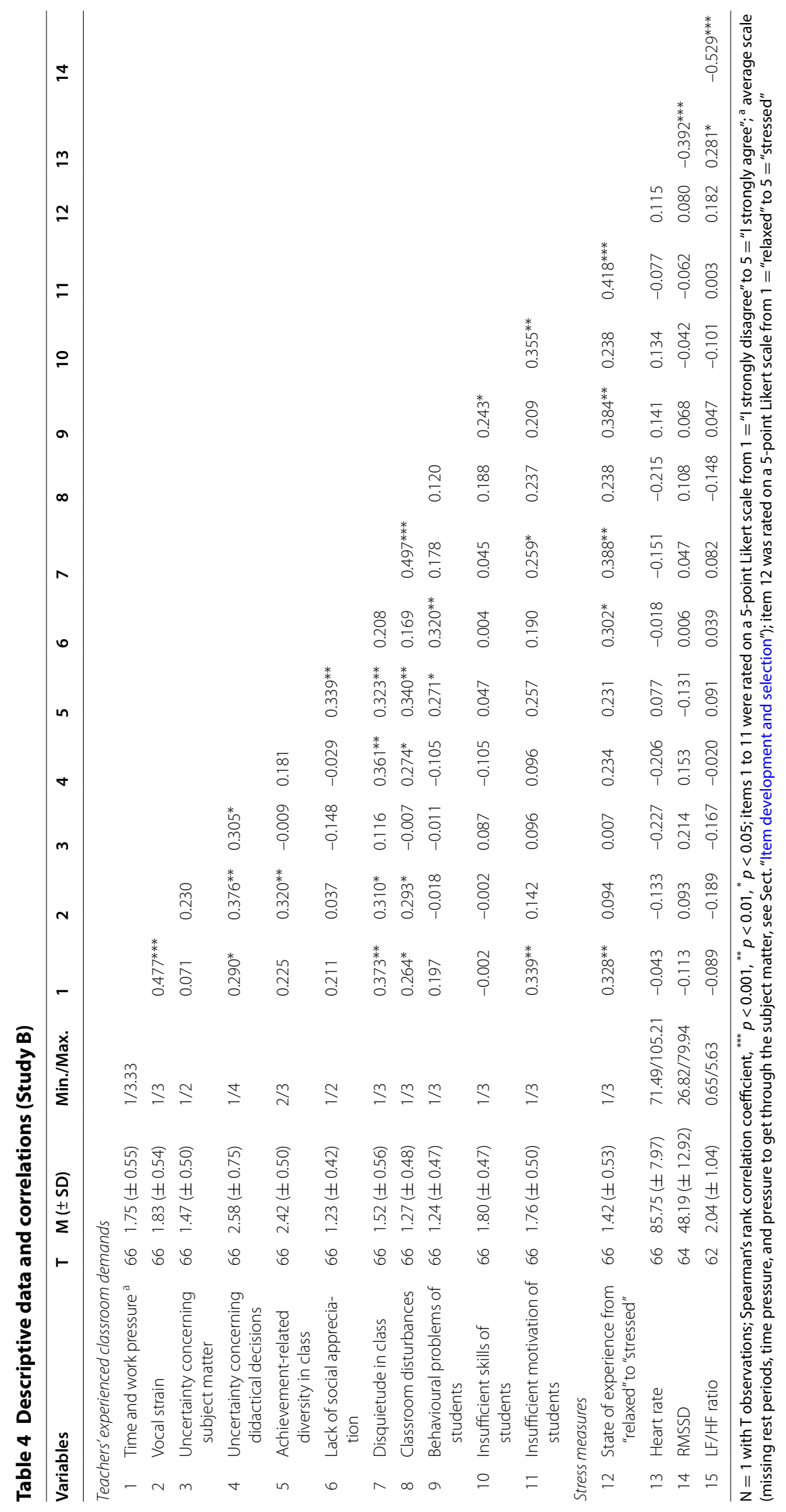


experience are consistently positively associated with assessed classroom demands. There are no significant correlations between self-assessments (stress experience and experienced classroom demands) and ECG measures at time t. As one would expect, HR and RMSSD are significantly negatively associated $\left(r_{s}=-0.392\right)$, and HR and the LF/HF ratio are significantly positively associated $\left(r_{s}=0.281\right)$. Moreover, RMSSD and the LF/ HF ratio are significantly negatively associated $\left(r_{s}=-0.529\right)$.

\section{Time series analysis}

Examining time-lagged relationships between teachers' experienced classroom demands and autonomic stress reactions as well as between autonomic stress reactions and affective stress experience, we used an $\mathrm{N}=1$ time series analysis with a bivariate cross-lagged model for continuous dependent variables, which is also referred to as a first-order vector autoregressive [VAR(1)] model (Muthén and Muthén 1998-2017). We assessed all possible combinations of teachers' experienced classroom demands and autonomic markers as well as all possible combinations of autonomic markers and stress experience, and we report three models that contain marginally significant effects.

Corresponding to our hypotheses, in the following text, we will report relationships (a) between classroom demands and autonomic stress reactions as well as (b) between autonomic stress reactions and affective stress experience.

\section{Relationships between classroom demands and autonomic stress reactions}

Figure 2 illustrates the relationship between "I cannot respond to students' different needs" and the HR. Here, we expectedly found an almost significant ( $p=0.066)$ positive effect of the experienced demand of achievement-related diversity in class and the perceived responsibility to fulfill the teacher's role to respond to students' different needs (at time $t-1$ ) on the HR at time $t$. Thus, the more demanding the diversity in class at $t-1$ was evaluated by the participant, the higher was her HR at time $t$ (controlling for the significant autoregressive effect of $H R$ at time $t-1$ on $H R$ at time $\mathrm{t}$ ). The scatterplot illustrates the time-lagged relationship between "I cannot respond to students' different needs" $(t-1)$ and HR $(t)$.

Analogously, Fig. 3 illustrates the relationship between "There is disquietude in class" and the RMSSD. Here, we expectedly found an almost significant $(p=0.078)$ negative effect of the experienced demand of classroom disturbances through disruptive students (at time $t-1$ ) on the HRV indicator RMSSD at time $t$. Thus, the more demanding the classroom disturbances at $\mathrm{t}-1$ were evaluated by the participant, the lower was her RMSSD value at time t.

\section{Relationships between autonomic stress reactions and affective stress experience}

Assessing relationships between autonomic responses and subjective stress experience, we found a significant ( $p=0.016)$ time-lagged effect of the LF/HF ratio $(t-1)$ on the stress experience at time $t$ (Fig. 4 ). Thus, the higher the physiological arousal at time $t-1$, the higher the subjective stress experience at time $t$. 


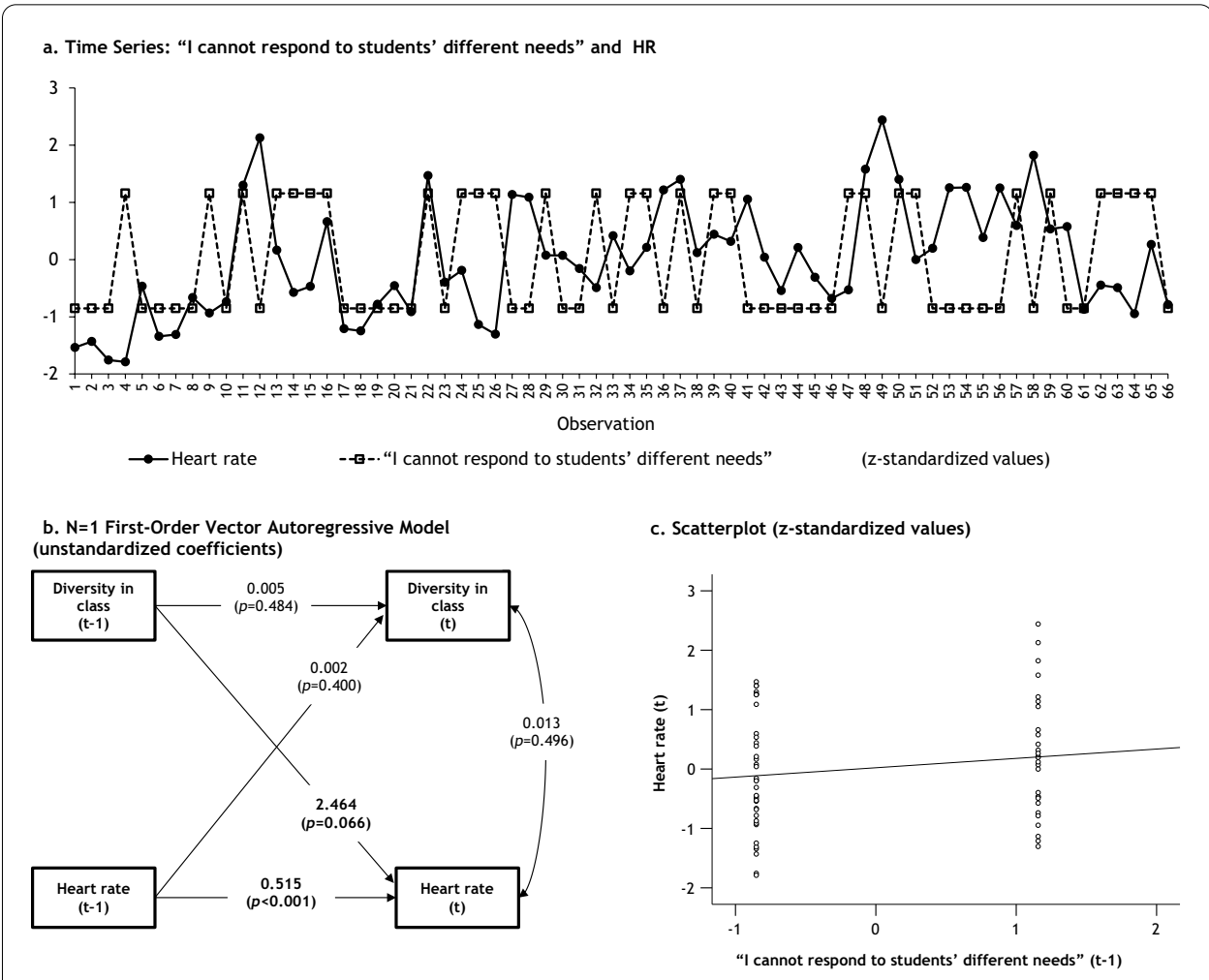

Fig. 2 "I cannot respond to students' different needs" and HR

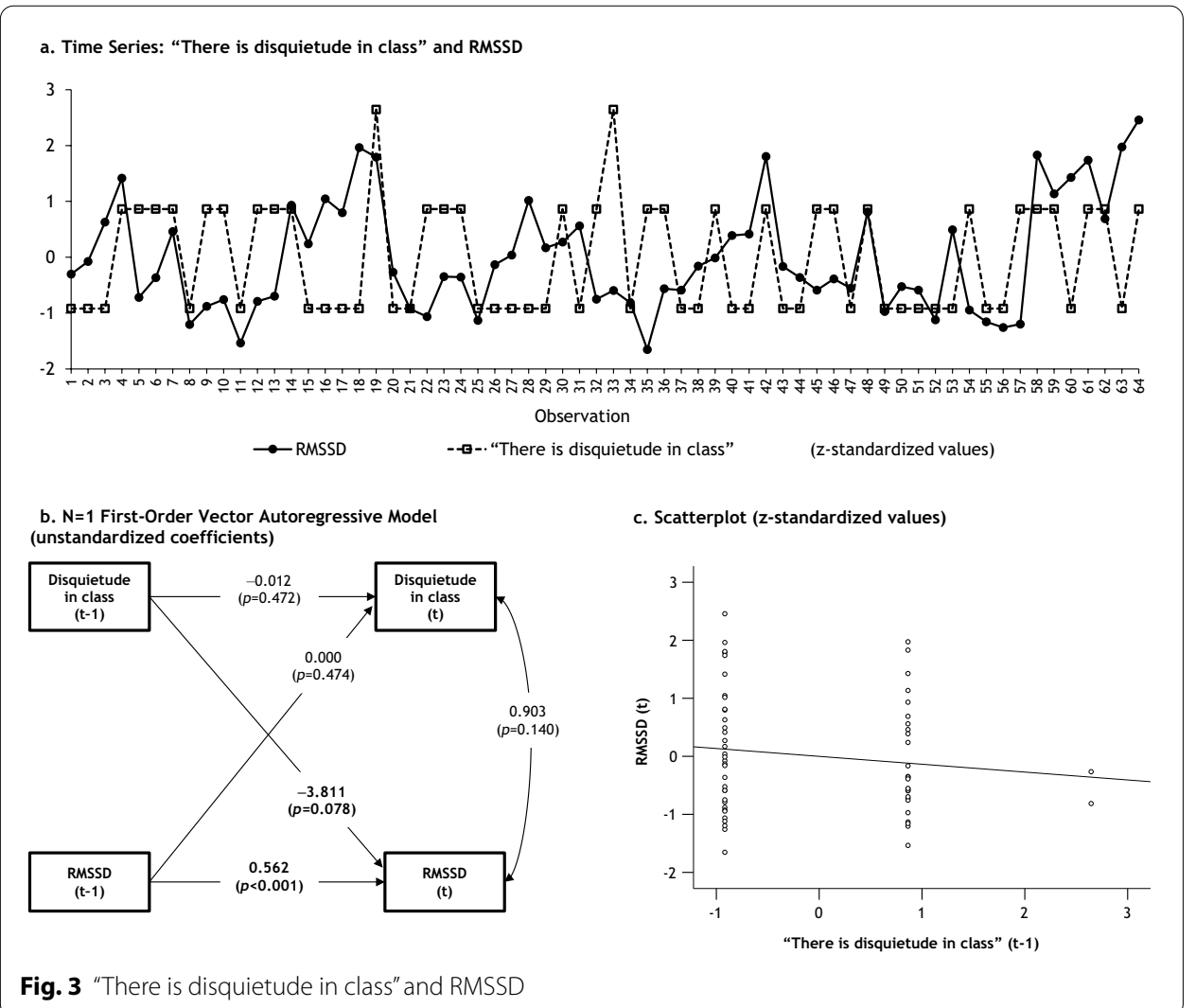




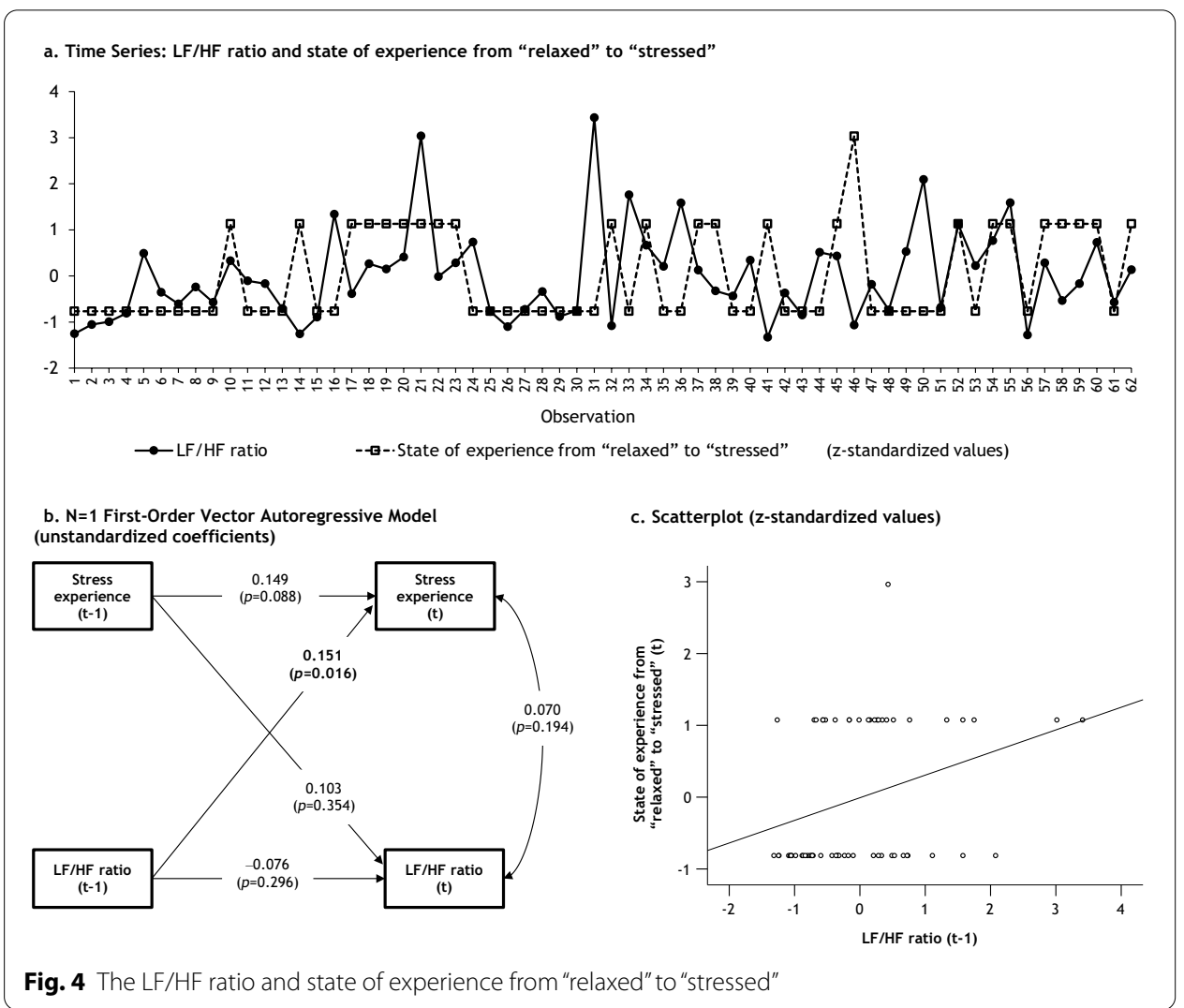

\section{Discussion}

\section{Summary of findings}

We conducted a pilot study to gain insights into relationships between teachers' experienced situational classroom demands and autonomic stress reactions as well as between autonomic stress reactions and affective stress experience. Via an integrative literature review, we first identified different categories that refer to teachers' situational classroom demands (Sect. "Literature review on teachers' situational classroom demands"). The identified categories were the basis for empirical item selection (Sect. "Study A: Empirical identification of teachers' classroom demands and item selection", Study A) as well as for the empirical examination of relationships between classroom demands and autonomic stress reactions via a single-case, short-term longitudinal study (Sect. 3, Study B). Concerning our hypotheses (Sect. "Research aims and hypotheses"), we found evidence that some of the experienced classroom demands ("I cannot respond to students' different needs"; "There is disquietude in class") had time-lagged associations with autonomic stress measures (see Figs. 2 and 3). Furthermore, we found that physiological arousal (the LF/HF ratio) triggers affective stress experience due to a time-lagged effect (see Fig. 4). 


\section{Limitations of the study}

There are some limitations of our pilot study. First, in Study A we used convenience sampling, which could lead to a lack of representation of the population concerning different teacher characteristics (e.g., age, teaching experience, school types). In addition, we examined relationships between classroom demands, autonomic stress reactions, and stress experience via a single-case study (Study B). This could be useful to gain experiences concerning methodological procedures, but the findings are not generalizable.

Because of the complexity of the referred model of teacher stress (Kyriacou and Sutcliffe 1978 et passim; Fig. 1) and the pilot character of our study, we limited our analysis to relationships between potential classroom stressors and teachers' stress reactions. Thus, future studies should consider personal appraisals of potential classroom stressors in addition to coping mechanisms as mediating variables. Including more participants in longitudinal field studies will also allow us to include relatively stable teacher characteristics in the analysis to examine, for example, effects of specific characteristics on individual growth trajectories or possible moderating effects of teacher characteristics on the relationship between situational classroom demands and physiological and affective response correlates of stress (e.g., Kaerner et al. 2017).

Concerning the theoretical modeling (see Sect. "Introduction"), the strict causal chain assumed would be the following: situational stimulus $(t-1) \rightarrow$ physiological response $(t) \rightarrow$ affective experience $(t+1)$. Because of the complexity of this assumption and the relatively small dataset (with only 66 observations), we were not able to analyze the entire causal chain with our data. Thus, we had to model two parts of the model separately: (a) situational stimulus $(\mathrm{t}-1) \rightarrow$ physiological response $(\mathrm{t})$ and $(\mathrm{b})$ physiological response $(t) \rightarrow$ stress experience $(t+1)$. In subsequent studies, it would be fruitful to examine empirically the abovementioned complete causal chain based on an extended sample of persons and observations.

Another limitation of Study B is that we do not have information about what was really going on in class. We only have the information provided by our single-case participant; this design restricts the validity of our findings because we only have one source of information. Thus, future studies should use video-based observations of what is going on in the classroom and use established coding systems such as the "Instrument to Identify Regulation Hindrances in Industrial Work" (RHIA) to identify regulation barriers and capacity-overtaxing factors in classroom teaching (Meder et al. 2008). Combining information about "objective" situational context conditions with information on self-reports along with physiological measures (e.g., Kaerner and Koegler 2016; Kaerner et al. 2017) seems to be fruitful and would give us better insights about teachers' stress in the classroom (for a good methodological example, see Donker et al. 2018).

\section{Conclusions and outlook}

Altogether, the study approach and the methodological procedures we used can be a fruitful basis for further investigations. In particular, the integration of psychophysiological research methods in vocational educational research could be advantageous because such methods provide "objective" data that is relatively independent from self-report biases (Dawson et al. 2011). However, referring to Selyes's (1973, p. 692) definition of 


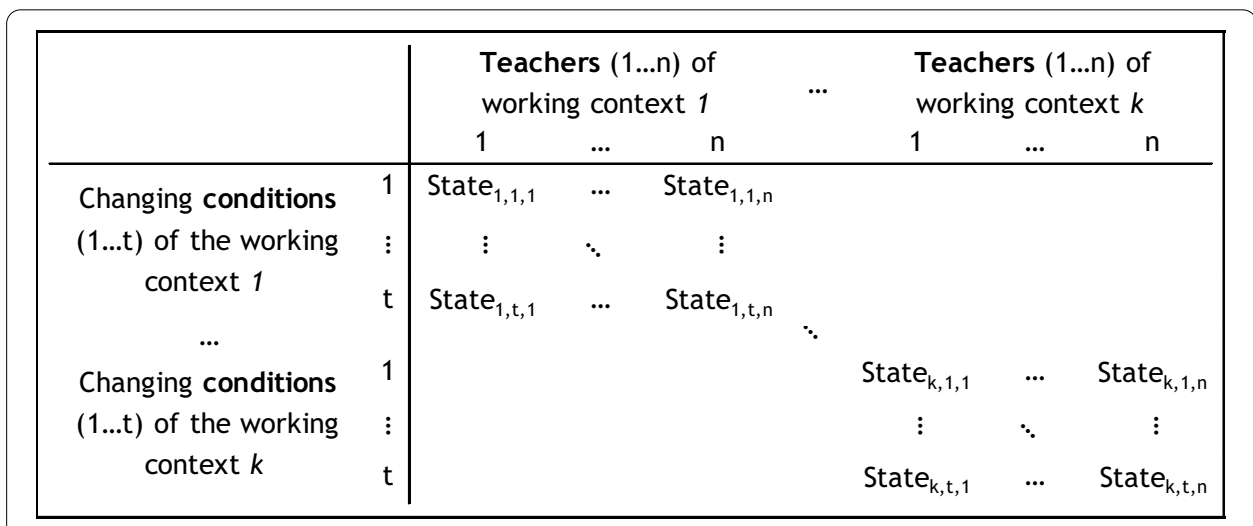

Fig. 5 Cross-classified data structure

stress as a "nonspecific response of the body to any demand made upon it," physiological measures are not meaningful per se, but they have to be interpreted in their interplay with particular context-related information (e.g., teachers' experienced classroom demands) (cf. Kaerner 2017). The research approach and results of our pilot study can be the basis for further process-oriented research in vocational education and training using a larger sample for an ambulatory physiological assessment and experience sampling study. From a practical point of view, our results on experienced classroom demands could be used in teacher education to prepare student teachers for specific skills to cope with such demands. In detail, the following framework could be an anchor for empirical and practical continue of work.

Taking into account that person-related situational behavioral, somatic, and psychological states are "nested" within persons (characterized by various traits relevant in the working context of teachers, such as, for instance, expertise and coping skills) and continuous changing conditions of the working context (such as, for instance, varying demands of the tasks teachers have to fulfill), more in-depth knowledge about the complex interrelations between traits, states, and continuous changing context conditions seems to be essential for a more holistic understanding of teacher stress. Thus, from a methodological point of view, the application of cross-classified data structures and corresponding multilevel statistical models (e.g., Heck et al. 2010) seems to be the method of choice. In that regard, cross-classification considers that multiple state measures are not only nested within persons, but that they also belong to observation units of the working context corresponding to the time of measurement (Goldstein 1994; Hill and Goldstein 1998; for applications see, for example, Kaerner and Koegler 2016; Kaerner et al. 2017; Kaerner and Warwas 2018). Figure 5 illustrates a cross-classified data structure with person-related states (e.g., varying HR or RMSSD values, or stress experience) nested within persons/teachers (1...n; e.g., varying levels of psychological resilience or coping skills) working in a specific working context (1...k; e.g., different types of schools) and exposed to continuously changing context conditions (1...t; e.g., varying levels of work-related demands).

With regard to high-frequency assessments of working conditions and continuously measured states, future research could focus on a "multidimensional mapping" of work-related contextual conditions and on an analysis of corresponding effects on 
person-related outcomes (e.g., well-being, stress). Such research could finally also result in empirically validated "multidimensional data cubes" that characterize the antecedents and effects of humane working environments for teachers (cf. Kaerner et al. 2017; Sembill and Kaerner 2020).

\begin{abstract}
Abbreviations
ANS: Autonomic nervous system; Bpm: Beats per minute; ECG: Electrocardiography; HF: High frequency (domain); HR: Heart rate; HRV: Heart-rate variability; Hz: Hertz; LF: Low frequency (domain); M: Mean value; Ms: Milliseconds; NN: Normal-to-normal; PNS: Parasympathetic nervous system; RMSSD: Square root of the mean of the sum of the squares of differences between adjacent NN intervals; SD: Standard deviation; SNS: Sympathetic nervous system; VAR model: Vector autoregressive model; VET: Vocational education and training.
\end{abstract}

\title{
Acknowledgements
}

We would like to thank Dr.-Ing. Stefan Hey (Karlsruhe Institute of Technology, Germany) who provided the measurement devices for the physiological measurement and gave advice concerning data analysis. Further, we would like to thank participants of Study A as well as our single-case participant (Study B). Finally, the authors would like to thank the anonymous reviewers for their critical, but very constructive comments and suggestions that help to improve the paper. Parts of the study were presented at the EARLI SIG 14 Biennial Conference (8th-10th July 2020), University of Barcelona, Spain (Book of abstracts of the EARLI SIG14 2020 Conference, p. 131, edited by G. París, C. Quesada-Pallarès, A. Ciraso-Calí, and H. Roig-Ester, https://dx.doi.org/10.6084/m9.figshare.12515342).

\section{Authors' contributions}

TK conceived, designed, and coordinated the study. He conceptualized the aim and structure of the research paper. Furthermore, he managed the literature searches, applied the statistical analyses, and wrote the paper. JH realized the data collection und literature review. All authors read and approved the final manuscript.

\section{Authors' information}

Tobias Kärner is visiting professor of business and economics education at the University of Hohenheim, Germany.

Jana Höning is trainee teacher at the Teachers College Stuttgart, Germany.

\section{Funding}

There are no sources of funding for the research.

\section{Availability of data and materials}

The data will not be shared publicly because for data protection reasons.

\section{Ethics approval and consent to participate}

The study was conducted in accordance with the Declaration of Helsinki, and all participants provided written, informed consent to participate.

\section{Consent for publication}

All participants provided written, informed consent for publication.

\section{Competing interests}

The author declares that he has no competing interests.

\section{Author details}

${ }^{1}$ University of Hohenheim, Stuttgart, Germany. ${ }^{2}$ Teachers College Stuttgart, Stuttgart, Germany.

Received: 9 September 2020 Accepted: 2 February 2021

Published online: 27 February 2021

\section{References}

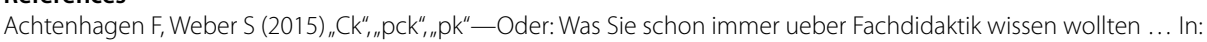
Rausch A, Warwas J, Seifried J, Wuttke E (eds) Konzepte und Ergebnisse ausgewaehlter Forschungsfelder der beruflichen Bildung - Festschrift fuer Detlef Sembill. Schneider Verlag Hohengehren, Baltmannsweiler, pp. 89-105 Baumert J, Kunter M (2006) Stichwort: Professionelle Kompetenz von Lehrkraeften. Z Erziehwiss 9(4):469-520

Beck K (1994) Das Leib-Seele-Problem und die Erziehungswissenschaft. Ein Orientierungsversuch. In: Pollack G, Heid H (eds) Von der Erziehungswissenschaft zur Paedagogik? Deutscher Studien-Verlag, Weinheim, pp 227-267

Belt A, Belt P (2017) Teachers' differing perceptions of classroom disturbances. Educ Res 59(1):54-72

Bieri T (2002) Die berufliche Situation aus der Sicht der Lehrpersonen. Zufriedenheit, Belastung, Wohlbefinden und Kuendigungen im Lehrberuf. Dissertation, Eberhard-Karls-Universitaet Tuebingen

Blase JJ (1986) A qualitative analysis of sources of teacher stress: consequences for performance. Am Edu Res J 23(1):13-40

Brown M, Ralph S (1998) The identification of stress in teachers. In: Dunham J, Varma V (eds) Stress in teachers past, present and future. Whurr Publishers, London, pp 37-56 
Bruehwiler C, Blatchford P (2011) Effects of class size and adaptive teaching competency on classroom processes and academic outcome. Learn Instr 21(1):95-108

Castaldo R, Melillo P, Bracale U, Caserta M, Triassi M, Pecchia L (2015) Acute mental stress assessment via short term HRV analysis in healthy adults: a systematic review with meta-analysis. Biomed Signal Process Control 18:370-377

Christ O, Van Dick R, Wagner U (2004) Belastung und Beanspruchung bei Lehrern in der Ausbildung [Burden and demand among teachers in training]. In: Hillert A, Schmitz E (eds) Psychosomatische Erkrankungen bei Lehrerinnen und Lehrern. Schattauer, Stuttgart, pp 113-119

Clays E, De Bacquer D, Crasset V, Kittel F, de Smet P, Kornitzer M, Karasek R, De Backer G (2011) The perception of work stressors is related to reduced parasympathetic activity. Int Arch Occup Environ Health 84:185-191

Corno L, Snow RE (1986) Adapting teaching to individual differences among learners. In: Wittrock MC (ed) Handbook of research on teaching. Macmillan, New York, pp 605-629

CoxT (1978) Stress. Macmillan, London

Dawson ME, Schell AM, Courtney CG (2011) The skin conductance response, anticipation, and decision-making. J Neurosci Psychol Econ 4(2):111-116

Donker MH, Van Gog T, Mainhard MT (2018) A quantitative exploration of two teachers with contrasting emotions: intraindividual process analyses of physiology and interpersonal behavior. FLR 6(3):162-185

Dubs R (1989) Zur Belastungssituation von Lehrkraeften. Eine Pilotstudie mit Lehrkraeften an kaufmaennischen Berufsschulen im Kanton St. Gallen. In: Dubs R, Hangartner Y, Nydegger A (eds) Der Kanton St. Gallen und seine Hochschule. Buchs Druck und Verlag, Buchs, pp 122-130

Dunham J (1981) Disruptive pupils and teacher stress. Educ Res 23:205-213

Dunham J, Bath V (1998) The benefits of whole-school stress management. In: Dunham J, Varma V (eds) Stress in teachers past, present and future. Whurr Publishers, London, pp 139-159

Dunham J, Varma V (eds) (1998) Stress in teachers past, present and future. Whurr Publishers, London

Friesen D, Williams MJ (1985) Organizational stress among teachers. Can J Educ 10(1):13-34

Garza JL, Cavallari JM, Eijckelhof BH, Huysmans MA, Thamsuwan O, Johnson PW, Dennerlein JT (2015) Office workers with high effort-reward imbalance and overcommitment have greater decreases in heart rate variability over a $2-h$ working period. Int Arch Occup Environ Health 88(5):565-575

Gebert D (1981) Belastung und Beanspruchung in Organisationen. Poeschel, Stuttgart

Goldstein H (1994) Multilevel cross-classified models. Sociol Methods Res 22(3):364-375

Grimm MA (1993) Kognitive Landschaften von Lehrern. Lang, Frankfurt

Haebler H, Kunz A (1985) Qualitaet der Arbeit und Verkuerzung der Arbeitszeit in Schule und Hochschule. Eine empirische Untersuchung im Auftrag der Max-Traeger-Stiftung, IMU-Institut, Munich

Heck RH, Thomas SL, Tabata LN (2010) Multilevel and longitudinal modeling with IBM SPSS. Routledge, New York

Heinrichs K, Reinke H (eds) (2019) Heterogenitaet in der beruflichen Bildung im Spannungsfeld zwischen Erziehung. Foerderung und Fachausbildung. wbv, Bielefeld

Helsper W (2003) Ungewissheit im Lehrerhandeln als Aufgabe der Lehrerbildung. In: Helsper W, Hoerster R, Kade J (eds) Ungewissheit. Paedagogische Felder im Modernisierungsprozess, Velbrueck Wissenschaft, Weilerswist, pp 142-161

Hernández-Gaytan SI, Rothenberg SJ, Landsbergis P, Becerril LC, De León-León G, Collins SM, Díaz-Vásquez FJ (2013) Job strain and heart rate variability in resident physicians within a general hospital. Am J Ind Med 56(1):38-48

Herzog S (2007) Beanspruchung und Bewaeltigung im Lehrerberuf. Waxmann, Muenster

Hill PW, Goldstein H (1998) Multilevel modeling of educational data with cross-classification and missing identification for units. J Educ Behav Stat 23(2):117-128

Hillert A, Koch S, Lehr D (2013) Das Burnout-Phaenomen am Beispiel des Lehrerberufs. Nervenarzt 84(7):806-812

Hjortskov N, Rissén D, Blangsted AK, Fallentin N, Lundberg U, Søgaard K (2004) The effect of mental stress on heart rate variability and blood pressure during computer work. Eur J Appl Physiol 92(1-2):84-89

Jaervelin-Pasanen S, Sinikallio S, Tarvainen MP (2018) Heart rate variability and occupational stress—systematic review. Ind Health 56(6):500-511

Kaegi DM, Halamek LP, Van Hare GF, Howard SK, Dubin AM (1999) Effect of mental stress on heart rate variability: validation of simulated operating and delivery room training modules. Pediatr Res 45(4):77A

Kaempf S, Krause A (2004) Gefährdungsbeurteilungen zur Analyse psychischer Belastungen am Arbeitsplatz Schule. In: Bungard W, Koop B, Liebig C (eds) Psychologie und Wirtschaft leben - Aktuelle Themen der Wirtschaftspsychologie in Forschung und Praxis. Rainer Hampp, Muenchen, pp 314-319

Kaerner T (2015) Erwartungswidrige Minderleistung und Belastung im kaufmaennischen Unterricht. Analyse paedagogischer, psychologischer und physiologischer Aspekte. Lang, Frankfurt

Kaerner T (2017) A mixed-methods study of physiological reactivity to domain-specific problem solving: methodological perspectives for process-accompanying research in VET. Empir Res Vocat Educ Train 9:10

Kaerner T, Koegler K (2016) Emotional states during learning situations and students' self-regulation: process-oriented analysis of person-situation interactions in the vocational classroom. Empir Res Vocat Educ Train 8:12

Kaerner T, Roehrig F, Warwas J (2020) Situative Anforderungscharakteristika lernprozessbegleitender Diagnostik im Unterricht: Systematisches Literaturreview und Fragebogenentwicklung [Situational demands of formative assessment of student learning during class: systematic literature review and questionnaire development]. Zeitschrift fuer Berufs- und Wirtschaftspaedagogik 116(4):643-676

Kaerner T, Sembill D, Aßmann C, Friederichs E, Carstensen CH (2017) Analysis of person-situation interactions in educational settings via cross-classified multilevel longitudinal modelling: illustrated with the example of students'stress experience. FLR 5(1):16-42

Kaerner T, Steiner N, Achatz M, Sembill D (2016) Tagebuchstudie zu Work-Life-Balance, Belastung und Ressourcen bei Lehrkraeften an beruflichen Schulen im Vergleich zu anderen Berufen. Zeitschrift fuer Berufs- und Wirtschaftspaedagogik 112(2):270-294

Kaerner T, Warwas J (2018) Stress im Unterricht? Prozessanalysen zu Interaktionseffekten unterrichtlicher Anforderungen und individueller Ressourcenbewertungen auf physische und psychische Stresssymptome von 
Berufsschueler/-innen Stress in the classroom? Process analysis of interaction effects between instructional demands and students' resource appraisals on physiological and psychological symptoms of stress among vocational students. Unterrichtswissenschaft 46(2):185-214

Kaerner T, Warwas J, Krannich M, Weichsler N (2021) How does information consistency influence prospective teachers' decisions about differentiated task assignments? A within-subject experiment to explain databased decision-making in heterogeneous classes. Learn Instr Online first: https://doi.org/10.1016/j.learninstr uc.2020.101440

Kemeny ME (2003) The psychobiology of stress. Curr Dir Psychol Sci 12(4):124-129

Kim HG, Cheon EJ, Bai DS, Lee YH, Koo BH (2018) Stress and heart rate variability: a meta-analysis and review of the literature. Psychiatry Investig 15(3):235-245

Kofman O, Meiran N, Greenberg E, Balas M, Cohen H (2006) Enhanced performance on executive functions associated with examination stress: evidence from task-switching and Stroop paradigms. Cogn Emot 20(5):577-595

Kounin J (1970) Discipline and group management in classrooms. Holt, Rinehart Winston, New York

Kramis-Aebischer K (1995) Stress. Belastungen und Belastungsverarbeitung im Lehrerberuf, Haupt, Bern

Krause A (2003) Lehrerbelastungsforschung-Erweiterung durch ein handlungspsychologisches Belastungskonzept. Zeitschrift fuer Paedagogik 49(2):254-273

Krause A (2004) Erhebung aufgabenbezogener psychischer Belastungen im Unterricht: Ein Untersuchungskonzept. Zeitschrift fuer Arbeits-und Organisationspsychologie 48(3):139-147

Krause A, Dorsemagen C (2007) Ergebnisse der Lehrerbelastungsforschung: orientierung im Forschungsdschungel. In: Rothland M (ed) Belastung und Beanspruchung im Lehrerberuf. VS Verlag fuer Sozialwissenschaften, Wiesbaden, pp 52-80

Kyriacou C (1998) Teacher stress: past and present. In: Dunham J, Varma V (eds) Stress in teachers past, present and future. Whurr Publishers, London, pp 1-13

Kyriacou C (2001) Teacher stress: directions for future research. Educ Rev 53(1):27-35

Kyriacou C (2011) Teacher stress: From prevalence to resilience. In: Langan-Fox J, Cooper CL (eds) New horizons in management. Edward Elgar Publishing, Cheltenham, Handbook of stress in the occupations, pp 161-173

Kyriacou C, Sutcliffe J (1978) Teacher stress: prevalence, sources, and symptoms. Br J Educ Psychol 48:159-167

Lazarus RS, Folkman S (1984) Stress, appraisal, and coping. Springer, New York

Li Z, Snieder H, Su S, Ding X, Thayer JF, Treiber FA, Wang X (2009) A longitudinal study in youth of heart rate variability at rest and in response to stress. Int J Psychophysiol 73(3):212-217

Lindholm H, Sinisalo J, Ahlberg J, Jahkola A, Partinen M, Hublin C, Savolainen A (2009) High job control enhances vagal recovery in media work. Occup Med 59(8):570-573

Loerbroks A, Schilling O, Haxsen V, Jarczok MN, Thayer JF, Fischer JE (2010) The fruits of ones labor: effort-reward imbalance but not job strain is related to heart rate variability across the day in 35-44-year-old workers. J Psychosom Res 69(2):151-159

Meder L, Dorsemagen C, Krause A (2008) Observational stress analysis at school: classroom teaching as an example of interaction work. Psychol Everyday Act 1(1):23-32

Miller R (1989) Sich in der Schule wohlfuehlen: Wege fuer Lehrerinnen und Lehrer zur Entlastung im Schulalltag. Beltz, Weinheim

Muthén LK, Muthén BO (1998-2017) Mplus user's guide. 8th edn. Muthén \& Muthén, Los Angeles

Needle RH, Griffin T, Svendsen R (1981) Occupational stress. Coping and health problems of teachers. J Sch Health 51(3):175-181

Papousek I, Nauschnegg K, Paechter M, Lackner HK, Goswami N, Schulter G (2010) Trait and state positive affect and cardiovascular recovery from experimental academic stress. Biol Psychol 83(2):108-115

Paseka A, Keller-Schneider M, Combe A (eds) (2018) Ungewissheit als Herausforderung fuer paedagogisches Handeln. Springer, Wiesbaden

Pieren F, Schaerer A (1994) Lehrer-und Lehrerinnenbelastungen: Eine Untersuchung an Erst-und Viertklasslehrkraeften im Kanton Bern. Bildungsforschung und Bildungspraxis 16(2):185-210

Rausch A (2011) Erleben und Lernen am Arbeitsplatz in der betrieblichen Ausbildung. Springer, Wiesbaden

Ritterstaedt U, Paulsen R, Kastka J (1980) Geraeuschsituationen in und um Schulen unter Beruecksichtigung der Belastung der Lehrer durch Laerm. Westdeutscher Verlag, Opladen

Rothland M (2009) Das Dilemma des Lehrerberufs sind ... die Lehrer? Z Erziehwiss 12(1):111-125

Rothland M, Terhart E (2007) Beruf: Lehrer - Arbeitsplatz Schule: Charakteristika der Arbeitstaetigkeit und Bedingungen der Berufssituation. In: Rothland M (ed) Belastung und Beanspruchung im Lehrerberuf. VS Verlag fuer Sozialwissenschaften, Wiesbaden, pp 52-80

Rudow B (1994) Die Arbeit des Lehrers: Zur Psychologie der Lehrertaetigkeit. Lehrerbelastung und Lehrergesundheit, Hans Huber, Bern

Rudow B (2000) Der Arbeits-und Gesundheitsschutz im Lehrerberuf: Gefaehrdungsbeurteilung der Arbeit von Lehrerinnen und Lehrern. Sueddeutscher Paedagogischer Verlag, Ludwigsburg

Schaarschmidt U, Kieschke U (2007) Beanspruchungsmuster im Lehrerberuf: Ergebnisse und Schlussfolgerungen aus der Potsdamer Lehrerstudie. In: Rothland M (ed) Belastung und Beanspruchung im Lehrerberuf. VS Verlag fuer Sozialwissenschaften, Wiesbaden, pp 81-98

Schachter S, Singer J (1962) Cognitive, social, and physiological determinants of emotional state. Psychol Rev 69(5):379-399

Schallberger U (2005) Kurzskalen zur Erfassung der Positiven Aktivierung, Negativen Aktivierung und Valenz in Experience Sampling Studien (PANAVA-KS) Forschungsberichte aus dem Projekt: "Qualitaet des Erlebens in Arbeit und Freizeit" Nr. 6. Psychologisches Institut der Universitaet Zuerich, Zuerich

Schoenwaelder HG, Berndt J, Stroever F, Tiesler G (2003) Belastung und Beanspruchung von Lehrerinnen und Lehrern. Wirtschaftsverlag NW, Bremerhaven, Schriftenreihe der Bundesanstalt fuer Arbeitsschutz und Arbeitsmedizin

Schubert C, Lambertz M, Nelesen RA, Bardwell W, Choi JB, Dimsdale JE (2009) Effects of stress on heart rate complexitya comparison between short-term and chronic stress. Biol Psychol 80(3):325-332 
Schumann S (2019) Belastungserleben von angehenden Lehrpersonen der Sekundarstufe II in der Schweiz und in Deutschland. In: Holtsch D, Oepke M, Schumann S (eds) Lehren und Lernen auf der Sekundarstufe II. Gymnasialund wirtschaftspaedagogische Perspektiven. hep, Bern, pp 430-440

Seiboth F (2015) Psychische Belastung und Gesundheit von Lehrkraeften im Raum Magdeburg: Ein Altersgruppenvergleich. Dissertation, Otto-von-Guericke-Universitaet Magdeburg

Seifried J (2009) Unterricht aus der Sicht von Handelslehrern. Lang, Frankfurt

Seifried J, Sembill D (2005) Emotionale Befindlichkeit in Lehr-Lern-Prozessen in der beruflichen Bildung. Zeitschrift fuer Paedagogik 51(5):656-672

Selye H (1973) The evolution of the stress concept. Am Sci 61(6):692-699

Sembill D (1987) Wirtschaftslehreunterricht: Einige Forschungsergebnisse zum Zusammenhang von Verbalurteilen und Handeln am Beispiel der Unterrichtseinheit "Kaufvertrag" [Economics education: Research results on relationships between teacher judgements and teachers" didactical actions in the teaching unit 'purchase contract']." Zeitschrift fuer Berufs-und Wirtschaftspaedagogik 83:213-232

Sembill D (2004) Abschlussbericht zu "Prozessanalysen Selbstorganisierten Lernens" im Rahmen des DFG-Schwerpunktprogramms „Lehr-Lern-Prozesse in der kaufmaennischen Erstausbildung”. https://www.uni-bamberg.de/fileadmin/ uni/fakultaeten/sowi_lehrstuehle/wirtschaftspaedagogik/Dateien/Forschung/Forschungsprojekte/Prozessana lysen/DFG-Abschlussbericht_sole.pdf. Accessed January 25, 2021

Sembill D (2015) Berufliche Bildung in einer Lerngesellschaft. In: Weber A, Peschkes L, De Boer WEL (eds) Return to work Arbeit fuer alle. Gentner, Stuttgart, pp 83-93

Sembill D, Kaerner T (2018) Bewertung und Ausbalancierung - Heuristiken fuer onto-und soziogenetische Schichtungsmodellierungen in der Bildungsforschung. In: Huber M, Krause S (eds) Bildung und Emotion. Springer VS, Wiesbaden, pp 169-194

Sembill D, Kaerner T (2020) Emotionen sind Macht. Analoge und digitale Rhythmen in der Fortschrittsdebatte der beruflichen Lehrpersonenbildung. In: Heinrichs K, Koegler K, Siegfried Ch (eds) Berufliches Lehren und Lernen: Grundlagen, Schwerpunkte und Impulse wirtschaftspaedagogischer Forschung. https://www.bwpat.de/profi 16_wuttke/sembill_kaerner_profil6.pdf. Accessed Jan 252021

Solman R, Feld M (1989) Occupational stress: Perceptions of teachers in catholic schools. J Educ Admin 27:55-68

Soltau A, Mienert M (2010) Unsicherheit im Lehrerberuf als Ursache mangelnder Lehrerkooperation? Eine Systematisierung des aktuellen Forschungsstandes auf Basis des transaktionalen Stressmodells. Zeitschrift fuer Paedagogik 56(5):761-778

Spanhel D, Hueber HG (1995) Lehrersein heute—berufliche Belastungen und Wege zu deren Bewaeltigung. Klinkhardt, Bad Heilbrunn

Stiller M (2015) Belastungen. Ressourcen und Beanspruchungen bei Lehrkraeften, Klinkhardt, Bad Heilbrunn

Taelman J, Vandeput S, Vlemincx E, Spaepen A, Van Huffel S (2011) Instantaneous changes in heart rate regulation due to mental load in simulated office work. Eur J Appl Physiol 111(7):1497-1505

Task Force of The European Society of Cardiology and The North American Society of Pacing and Electrophysiology (1996) Heart rate variability —standards of measurement, physiological interpretation, and clinical use. Eur Heart J 17:354-381

Terhart E (2014) Umgang mit Heterogenitaet: Anforderungen an Professionalisierungsprozesse. Lehren und Lernen 8(9):7-12

Tharion E, Parthasarathy S, Neelakantan N (2009) Short-term heart rate variability measures in students during examinations. Natl Med J India 22(2):63-66

Trachsler E, Brueggen S, Nido M, Ulich E, Inversini S, Wuelser M, Herms I (2006) Arbeitsbedingungen, Belastungen und Ressourcen der Thurgauer Volksschullehrkraefte angesichts der laufenden Bildungsoffensive. Ergebnisse der zweiten Erhebung 2005 (Forschungsbericht Nr. 4/April 2006). Paedagogische Hochschule Thurgau, Kreuzlingen

Traina M, Cataldo A, Galullo F, Russo G (2011) Effects of anxiety due to mental stress on heart rate variability in healthy subjects. Minerva Psichiatr 52(4):227-231

Uusitalo A, Mets T, Martinmaeki K, Mauno S, Kinnunen U, Rusko H (2011) Heart rate variability related to effort at work. Appl Ergon 42(6):830-838

Van Dick R (1999) Stress und Arbeitszufriedenheit im Lehrerberuf: Eine Analyse von Belastung und Beanspruchung im Kontext sozialpsychologischer, klinisch-psychologischer und organisationspsychologischer Konzepte. Tectum, Marburg

Verhagen SJW, Hasmi L, Drukker M, van Os J, Delespaul PAEG (2016) Use of the experience sampling method in the context of clinical trials. Evid Based Mental Health 19(3):86-89

Warwas J, Kaerner T, Geck AL (2016) Individuelle und kontextuelle Praediktoren intrinsischer Lernmotivation von Auszubildenden an beruflichen Schulen (Individual and contextual predictors of apprentices' intrinsic learning motivation in vocational schools). Zeitschrift fuer Bildungsforschung 6(3):285-306

Weinert FE, Schrader FW (1986) Diagnose des Lehrers als Diagnostiker. In: Petillon H, Wagner J, Wolf B (eds) Schuelergerechte Diagnose. Theoretische und empirische Beitraege zur Paedagogischen Diagnostik, Beltz, Weinheim, pp $11-29$

Wulk J (1988) Lehrerbelastung. Qualitative und quantitative Aspekte der psychischen und physischen Belastung von Lehrern. Eine Arbeitspsychologische Untersuchung an Lehrern beruflicher Schulen. Lang, Frankfurt

Wuttke E (2005) Unterrichtskommunikation und Wissenserwerb: Zum Einfluss von Kommunikation auf den Prozess der Wissensgenerierung. Lang, Frankfurt

\section{Publisher's Note}

Springer Nature remains neutral with regard to jurisdictional claims in published maps and institutional affiliations. 